\title{
Evaluation of In vitro Antidiabetic Potential of Thymus schimperi $R$. and Thymus vulgaris $L$.
}

\author{
Engeda Dessalegn $^{1 *} \quad$ Geremew Bultosa $^{2} \quad$ Gulelat Desse Haki ${ }^{2} \quad$ H. P. Vasantha Rupasinghe ${ }^{3}$ \\ 1.Chemistry department, Hawassa College of Education, , P.O. Box 115, Hawassa, Ethiopia \\ 2.Department of Food Science and Technology, Botswana University of Agriculture and Natural Resource, \\ Private Bag 0027, Gaborone, Botswana \\ 3.Department of Environmental Sciences, Faculty of Agriculture, Dalhousie University P.O. Box 550, Truro, \\ Nova Scotia B2N 5E3, Canada
}

\begin{abstract}
Diabetes has become the most common metabolic disease worldwide. In particular, type 2 diabetes is the most commonly encountered type of diabetes, which is characterized by impaired insulin secretion and/or action. One of the effective methods to control diabetes is to inhibit the activity of $\alpha$-amylase and $\alpha$-glucosidase enzymes which are responsible for the breakdown of starch to more simple sugars, using plant products. This study evaluated the total phenolic (TPC), total flavonoid (TFC), and antidiabetic potential of Thymus schimperi and Thymus vulgaris via in vitro inhibition of $\alpha$-amylase and $\alpha$-glucosidase, using the hot water and aqueous: methanol $(20: 80, \mathrm{v} / \mathrm{v})$ extracts. The $\alpha$-amylase inhibitory potentials of the extracts were investigated through reducing sugars analysis using 3,5-dinitrosalicylic acid color reagent (DNSA) using starch solution as substrate. The $\alpha$-glucosidase inhibition was determined by pre-incubating $\alpha$-glucosidase with different concentrations of the extracts followed by the addition of p-nitrophenylglucopyranoside (pNPG). Aqueous: methanol (20:80, v/v) extract of $T$. schimperi contained highest TPC $(46.01 \pm 4.54 \mathrm{mg} \mathrm{GAE} / \mathrm{g} \mathrm{dw})$ and TFC $(14.72 \pm 1.14 \mathrm{mg} \mathrm{QE} / \mathrm{g} \mathrm{dw})$ also showed stronger $\alpha$-amylase inhibition activity $\left(\mathrm{IC}_{50}=0.33 \pm 0.05 \mathrm{mg} / \mathrm{mL}\right)$ and the hot water extract exhibited stronger $\alpha$-glucosidase inhibition $\left(\mathrm{IC}_{50}=0.05 \pm 0.01 \mathrm{mg} / \mathrm{mL}\right)$ capacity than that of $T$. vulgaris. The TPC and TFC were positively related $(\mathrm{p}<0.05)$ with $\alpha$-amylase inhibition activity but negatively correlated $(\mathrm{p}>0.05)$ with $\alpha$-glucosidase inhibitory activity. These results indicated that the inhibition of these enzymes can lead to lower postprandial blood glucose. Keywords: $\alpha$-Amylase, Antidiabetic, Diabetes mellitus, $\alpha$-Glucosidase, Thymus, Total phenolics
\end{abstract}

DOI: $10.7176 / \mathrm{JHMN} / 69-02$

Publication date: December $31^{\text {st }} 2019$

\section{Introduction}

Diabetes mellitus is a metabolic disease characterized by hyperglycemia and disturbances in fat and protein metabolism that results from defects in both insulin secretion and/or insulin action. In particular, type 2 diabetes mellitus is the most encountered form of diabetes, accounting for more than $80 \%$ of the total cases of diabetes (Chan et al., 2010). Various pharmacological approaches have been used to improve diabetes via different modes of action including stimulation of insulin release, inhibition of gluconeogenesis, increasing the number of glucose transporters and reduction of glucose absorption from the intestine (Ahmed et al., 2010). One of the most effective ways of controlling postprandial hyperglycaemia is to suppress starch digestion as it is the main contributor of glucose in the human body from diet. Suppression of starch hydrolysis is conducted through the inhibition of carbohydrate hydrolyzing enzymes such as $\alpha$-amylase and $\alpha$-glucosidase in the digestive organs (Mustafa et al., 2010). Inhibitors of these enzymes delay carbohydrate digestion and prolong the overall time for carbohydrate digestion, resulting in a decrease in the rate of glucose absorption (Yang et al., 2012).

Traditional medicinal plants have been used for many years by different cultures around the world for the management of diabetes. In recent years, investigation on herbal medicines has become progressively important in the search for a new, effective and safe therapeutic agent for the treatment of diabetes. Many pure bioactive compounds isolated from plants have been demonstrated to have blood glucose-lowering effect, several of which are flavonoids (Kati et al., 2010), triterpenoids (Wenli et al., 2009), carotenoids (Miaad and Saeed, 2017), and alkaloids (Soon et al., 2013). Studies indicated that some of the dietary plants possessed inhibitory effect against $\alpha$-glycosidase and or $\alpha$-amylase, such as sorghum, foxtail millet and proso millet, (John et al., 2014) guava leaves (Shakeera et al., 2013) and eggplant (Esther et al., 2013). In addition, in vitro inhibitory activities have been reported for phenolic extracts of foods, including fruits (Jayaprakasam et al., 2005; Castañeda-Ovando et al., 2009; Misbah, 2013), vegetables (Oboh et al., 2012), medicinal herbs (Abdullah and Izabela, 2013), green and black tea (Kati et al., 2010 ), and berries (McDougall et al., 2005).

Even nowadays some spices and culinary herbs play an important role in primary health care and in the treatment of diabetes, especially in developing countries (Wongsa, 2012). Natural hypoglycemic compounds may be attractive alternatives to synthetic drugs or reinforcements to currently used treatments. Their huge advantage is that they can be ingested in everyday diet. T. schimperi Ronniger is a wild endemic herb to Ethiopia and is traditionally used for food flavoring as well as medicinal ingredient. The dried leaves are used to flavor tea, coffee, 
food and also boiled as a tea substitute and are believed to be good for diabetic patients (Nigist \& Sebsebe, 2009). T. vulgaris L. is an important medicinal plant (Golmakani and Rezaei, 2008; Al-Bayati, 2008) which has been used for centuries as spice, home remedy, drug, perfume and insecticide, and also reported to have antidiabetic activity (Rime et al., 2014). So far, there are few studies on $\alpha$-amylase inhibition activities of the dried leaf $T$. schimperi (Engeda et al., 2015). Therefore, the objective of the present study was to compare TPC, TFC and in vitro antidiabetic potentials of hot water and aqueous: methanol $(20: 80, \mathrm{v} / \mathrm{v})$ extracts of the dried leaves of $T$. schimperi and T. vulagaris. Also correlation between total phenolic contents and $\alpha$-amylase and $\alpha$-glucosidase inhibition capacity of these herbs was evaluated.

\section{Materials and Methods}

\subsection{Chemicals}

Gallic acid, Folin-Ciocalteu reagent, quercetin, acarbose, 3, 5-dintrosalicylic acid (DNSA), potato starch, phosphate buffer, sodium chloride, sodium carbonate, aluminum chloride, sodium potassium tartarate, $\alpha$ glucosidase, $\alpha$-amylase, and p-nitrophenyl- $\alpha$-D-glucopyranoside were purchased from Sigma-Aldrich. The other chemicals and solvents used in this experiment were of analytical reagent grades.

\subsection{Sample preparation and extraction}

Fresh leaves of T. schimperi Ronniger were collected from Dinsho, Bale Mountain National Park, South East Ethiopia and fresh leaf of T. vulgaris was collected from garden in Dalhousie Agricultural College, Canada. The leaves were air dried for 10 days and then ground to fine powder using electric grinder (FM100 model, China). The hot water and aqueous: methanol $(20: 80, \mathrm{v} / \mathrm{v})$ extracts were prepared by dissolving $1 \mathrm{~g}$ of the leaf fine powder separately in $10 \mathrm{~mL}$ each solvent. The hot water extract was heated for $5 \mathrm{~min}$ using water bath. The mixtures were then subjected to sonication (model 750D, VWR Intl. Ltd., Montreal, QC, Canada) for $15 \mathrm{~min}$ x 3 times, with 10 min intervals in between sonication cycles to keep the temperature below $30^{\circ} \mathrm{C}$ during the extraction. After centrifugation (model Durafuge 300, Precision Scientific, Richmond, VA, USA) at $5000 \mathrm{rpm}$ for $10 \mathrm{~min}$, the supernatant was filtered using Whatman number 1 filter paper. The methanol was evaporated from aqueous: methanol $(20: 80, \mathrm{v} / \mathrm{v})$ extract under $\mathrm{N}_{2}$ and the remaining water (in aqueous: methanol (20:80, $\mathrm{v} / \mathrm{v}$ extract) and hot water extract were freeze dried for 10h using freeze drier (model 2085C0000, Kinetics Thermal Systems, Stone Ridge, NY, USA). Samples of each treatment were extracted and analyzed in triplicate and immediately stored in amber vials at $-20^{\circ} \mathrm{C}$ until used for analysis.

\subsection{Determination of total phenolic content (TPC)}

The TPC was estimated by Folin-Ciocalteu method as described in Shan et al. (2005) with slight modification using gallic acid as the standard. To $0.1 \mathrm{~mL}$ of the extract, $1 \mathrm{~mL}$ Folin- Ciocalteu reagent (diluted ten times) was added and the mixture was left for $5 \mathrm{~min}$ and then $1 \mathrm{~mL}(75 \mathrm{~g} / \mathrm{L})$ of sodium carbonate was added. The absorbance of the resulting blue color was measured at $765 \mathrm{~nm}$ with a UV-Visible spectrophotometer (JENWAY, 96500, UK) after incubation for $90 \mathrm{~min}$ at room temperature. The TPC was estimated from gallic acid $(1-100 \mu \mathrm{g} / \mathrm{mL})$ calibration curve $(\mathrm{y}=0.015 \mathrm{x}+0.09, \mathrm{R} 2=0.99)$ and the results were expressed as milligram gallic acid equivalent/gram of dried plant material ( $\mathrm{mg} \mathrm{GAE} / \mathrm{g} \mathrm{dw})$.

\subsection{Determination of total flavonoid content (TFC)}

The TFC was determined as described in Ayoola et al. (2008) with minor modifications. The analysis was based on the formation of yellow color of flavonoid-aluminum complex. Aluminum chloride $(2 \mathrm{~mL}, 2 \%)$ was mixed with the same volume of the leaf extract $(1 \mathrm{mg} / \mathrm{mL})$. Individual blanks were prepared consisting of $2 \mathrm{~mL}$ of sample solution and $2 \mathrm{~mL}$ of methanol without aluminum chloride. Then absorbance readings at $415 \mathrm{~nm}$ were taken after $1 \mathrm{~h}$ of incubation at room temperature against a blank sample. The TFC was determined using a standard curve (y $\left.=0.24 \mathrm{x}+0.11, \mathrm{R}^{2}=0.98\right)$ of quercetin $(1-40 \mu \mathrm{g} / \mathrm{mL})$ and values were calculated as milligram quercetin equivalents/gram of dried plant material ( $\mathrm{mg} \mathrm{QRE} / \mathrm{g} \mathrm{dw})$.

\subsection{Porcine pancreatic $\alpha$-amylase inhibition assay (DNSA method)}

The DNSA assay for reducing sugar was conducted using various crude extracts of the leaves and starch as a substrate for amylase enzyme as described in Kwon et al. (2008) with minor modification. Test samples $200 \mu \mathrm{L}$ (0.01- $2.5 \mathrm{mg} / \mathrm{mL}$ ) in a $0.02 \mathrm{M}$ sodium phosphate buffer solution $(\mathrm{pH} 6.9$ with $0.006 \mathrm{M}$ sodium chloride) containing $200 \mu \mathrm{L}$ Porcine pancreatic $\alpha$-amylase were incubated at $25^{\circ} \mathrm{C}$ for $10 \mathrm{~min}$, after which, $200 \mu \mathrm{L}$ of $1 \%$ boiled potato starch solution in $0.02 \mathrm{M}$ sodium phosphate buffer solution ( $\mathrm{pH} 6.9$ with $0.006 \mathrm{M}$ sodium chloride) was added. After incubation of the reaction mixture at $25^{\circ} \mathrm{C}$ for $10 \mathrm{~min}$, the reaction was stopped by adding $400 \mu \mathrm{L}$ of DNSA reagent $(1.0 \mathrm{~g}$ of 3,5- dinitrosalicyclic acid, $20 \mathrm{~mL}$ of $2 \mathrm{M} \mathrm{NaOH}$ and $30 \mathrm{~g}$ of sodium potassium tartarate in 100 $\mathrm{mL}$ distilled water). The sample test tubes were then incubated in a boiling water bath for $5 \mathrm{~min}$ and cooled to room temperature. The reaction mixture was then diluted by adding $4 \mathrm{~mL}$ distilled water and absorbance of 200 
$\mu \mathrm{L}$ of brown solution of 3-amino-5-nitrosalicylic acid was measured at $540 \mathrm{~nm}$ using micro plate reader (FLUO star Optima, BMG Labtech, Durham, NC, USA). Distilled water (without amylase inhibitor) $(200 \mu \mathrm{L})$ was used as a control.

To remove matrix sugar interference, the absorbance of the mixture consisted of $200 \mu \mathrm{L}$ of sample (may contain reducing sugars), $200 \mu \mathrm{L}$ of phosphate buffer (no amylase), $200 \mu \mathrm{L}$ of starch, $400 \mu \mathrm{L} 3,5$ - dinitrosalicyclic acid, and $4 \mathrm{~mL}$ of distilled water was recorded at $540 \mathrm{~nm}$ as blank. Acarbose was used as reference. The $\alpha$-amylase inhibitory activity was expressed as \% inhibition and was calculated as shown below:

$\%$ inhibition $=\left[\mathrm{A}_{\text {control }}-\left(\mathrm{A}_{\text {sample }}-\mathrm{A}_{\text {blank }}\right) / \mathrm{A}_{\text {control }}\right] \times 100$

\section{6. $\alpha$-Glucosidase inhibition assay}

$\alpha$-Glucosidase inhibitory activities were evaluated according to the chromogenic method described by Ivan et al. (2012), with some modifications. The enzyme solution contained $20 \mu \mathrm{L} \alpha$-glucosidase $(0.5 \mathrm{unit} / \mathrm{mL}), 20 \mu \mathrm{L}$ of sample (at various concentrations) or drug (acarbose) and $60 \mu \mathrm{L} 0.01 \mathrm{M}$ phosphate buffer (pH 6.9). The mixture was incubated at $37{ }^{\circ} \mathrm{C}$ for $15 \mathrm{~min}$. After $15 \mathrm{~min}, 20 \mu \mathrm{L}$ of p-nitrophenyl- $\alpha$-D-glucopyranoside (pNP-G) $(5 \mathrm{mM})$ in the same buffer ( $\mathrm{pH}$ 6.9) was used as a substrate solution and again incubated at $37^{\circ} \mathrm{C}$ for $15 \mathrm{~min}$. The reaction (Figure 6.3) was terminated by adding $80 \mu \mathrm{L}$ of $0.2 \mathrm{M}$ sodium carbonate solution. Each experiment was conducted in triplicate. The change in the absorption observed at $405 \mathrm{~nm}$ due to the hydrolysis of p-nitrophenyl- $\alpha$-Dglucopyranoside (pNP-G) was monitored in a 96-well plate with micro plate reader (FLUO star Optima, BMG Labtech, Durham, NC, USA). Increase in absorption at $405 \mathrm{~nm}$ was due to enzyme activity as the enzyme hydrolyzes the pNP-G to release p-nitrophenolate ion. The temperature was maintained at $37^{\circ} \mathrm{C}$ during the experiment. The positive control sample was the mixture of the enzyme $(20 \mu \mathrm{L})$ and substrate $(20 \mu \mathrm{L})$ without inhibitors. Instead $20 \mu \mathrm{L}$ of working buffer was added. The sample controls and blanks were the mixtures of sample and control, respectively, except $\alpha$-glucosidase which was replaced instead with buffer. The $\mathrm{IC}_{50}$ values of samples were calculated and reported as the mean \pm SD of the three experiments. The enzyme inhibitory rates of samples were calculated as follows:

Inhibition $\left.\%=\left[\left(\mathrm{A}_{\mathrm{S}}-\mathrm{A}_{\mathrm{SB}}\right) / \mathrm{A}_{\mathrm{C}}-\mathrm{A}_{\mathrm{CB}}\right)\right] \mathrm{x} 100$

Where, $A_{S}, A_{S B}, A_{C}, A_{C B}$ are the absorbance of sample, sample blank, control, and control blank, respectively.

\subsection{Statistical analysis}

The data were subjected to analysis of variance (ANOVA) and Duncan's multiple range tests were used for mean separation at $\mathrm{p}<0.05$. Linear regression analysis was used to calculate $\mathrm{IC}_{50}$ value. Pearson correlations among antioxidant activities, total phenolic and flavonoid contents were considered at $p<0.05$.

\section{Result and Discussions}

\subsection{Total phenolic and flavonoid contents}

The TPC in various solvent extracts from the leave of T. schimperi and T. vulgaris varied widely, ranging from $15.65 \pm 4.01$ to $46.0 \pm 4.5 \mathrm{mg} \mathrm{GAE} / \mathrm{g} \mathrm{dw}$ (Table 1). The TPC content followed the order: aqueous: methanol (20:80, $\mathrm{v} / \mathrm{v})$ extract of $T$. schimperi $>$ aqueous: methanol $(20: 80, \mathrm{v} / \mathrm{v})$ extract of $T$. vulgaris $>$ hot water extract of $T$. schimperi $>$ hot water extract of T. vulgaris. There was no significant difference $(p>0.05)$ in TPC between aqueous: methanol $(20: 80, \mathrm{v} / \mathrm{v})$ extracts of $T$. schimperi and $T$. vulgaris but these values were significantly higher $(p<0.05)$ than the TPC of hot water extracts of T. shimperi and T. vulgaris. According to the study conducted by Hasya et al. (2019), Thymus zygioides var. lycaonicus showed stronger TPC (193.47 $\pm 4.45 \mathrm{mgGAE} / \mathrm{g})$ than that of both T. shimperi and T. vulgaris.

Table 1. Total phenolic (mgGAE/ g dw) and total flavonoid (mgQRE/g dw) contents of T. schimperi and T. vulgaris

\begin{tabular}{lll}
\hline \multicolumn{1}{c}{ Extract } & $\begin{array}{l}\text { TPC } \\
(\mathrm{mgGAE} / \mathrm{g} \mathrm{dw})^{*} \pm \mathrm{SD}\end{array}$ & $\begin{array}{l}\text { TFC } \\
(\mathrm{mgQRE} / \mathrm{g} \mathrm{dw})^{* *} \pm \mathrm{SD}\end{array}$ \\
\hline TS. ( aqueous: methanol:20:80, v/v) & $46.0 \pm 4.5^{\mathrm{c}}$ & $14.7 \pm 1.1^{\mathrm{c}}$ \\
TS (hot water) & $21.55 \pm 3.80^{\mathrm{b}}$ & $3.69 \pm 1.42^{\mathrm{a}}$ \\
TV ( aqueous: methanol:20:80, v/v) & $45.23 \pm 13.02^{\mathrm{c}}$ & $10.65 \pm 2.15^{\mathrm{b}}$ \\
TV (hot water) & $15.65 \pm 4.01^{\mathrm{a}}$ & $1.13 \pm 0.20^{\mathrm{a}}$ \\
\hline
\end{tabular}

TS: Thymus schimperi; TV: Thymus vulgaris; dw: dried weight of plant material. Where * and ** are total phenolic and total flavonoids expressed as gallic acid and quercetin equivalents per gram of dried weight , respectively. Values are expressed as mean $\pm \operatorname{SEM}(n=3)$ from triplicate experiments. Means with different letters in a column were significantly different at the level of $\mathrm{p}<0.05$.

The TFC (mg QRE/g dw) varied from $1.13 \pm 0.2$ to $14.7 \pm 1.1$ and decreased in the order of aqueous: methanol (20:80, v/v) extract of $T$. schimperi $>$ aqueous: methanol $(20: 80, \mathrm{v} / \mathrm{v})$ extract of $T$. vulgaris $>$ hot water extract of T. schimperi $>$ hot water of T. vulgaris (Table 1). TFC in aqueous: methanol $(20: 80, \mathrm{v} / \mathrm{v})$ extracts of $T$. schimperi and $T$. vulgaris were significantly different $(\mathrm{p}<0.05)$, but in the hot water extracts were not significantly different 
$(\mathrm{p}>0.05)$.

\subsection{Porcine $\alpha$-amylase inhibitory activity (DNSA method)}

One of the effective methods to control diabetes is to inhibit the activity of $\alpha$ - amylase enzyme which is responsible for the breakdown of starch to more simple sugars (Probhakar and Doble, 2011). This is contributed by $\alpha$ - amylase inhibitors, which delays the glucose absorption rate thereby maintaining the serum blood glucose in hyperglycemic individuals (Cazzola et al., 2011; Wadkar et al., 2008). Different studies have shown that phenolic compounds play a role in mediating $\alpha$-amylase inhibition and therefore have potential to contribute to the management of type 2 diabetes (Cheplick et al., 2010; Ranilla et al., 2010).

The extracts from the crude $T$. schimperi and $T$. vulgaris leaf extracts screened for in-vitro $\alpha$-amylase enzymes inhibitory activity. The results were shown in Figure 1. The $\alpha$-amylase enzymes inhibitory activity was concentration dependent. At $2.5 \mathrm{mg} / \mathrm{mL}$, the porcine $\alpha$-amylase inhibitory activity of aqueous: methanol (20:80, $\mathrm{v} / \mathrm{v}$ ) extract from $T$. shimperi was $68.6 \pm 5.9 \%$, and the inhibitory activity of its boiling water extract was $48.7 \pm$ $7.1 \%$. The inhibitory activity of aqueous: methanol $(20: 80, \mathrm{v} / \mathrm{v})$ extract from T. vulagaris was $60.7 \pm 9.2 \%$, and the inhibitory activity of its boiling water extract reached $27.1 \pm 3.9 \%$. Aqueous: methanol (20:80, v/v) extracts of $T$. shimperi demonstrated stronger percentage of $\alpha$-amylase enzyme inhibitory activities than that of $T$. vulgaris extracts. These values are lower than citronella grass, lemongrass oils (Jumepaeng et al., 2013) and finger millet (Shobana et al., 2009 ), but higher than cereal grains such as wheat, buckwheat, corn and oats (Randhir et al., 2008) and foxtail millet (Kim et al., 2011). As positive control, at the concentration of $2.5 \mathrm{mg} / \mathrm{mL}$, acarbose showed the strongest $\alpha$-amylase inhibition activity $(98.9 \pm 8.8 \%)$.

The inhibitory activity was determined as the mean of triplicate measurements and expressed as the $50 \%$ inhibitory concentrations $\left(\mathrm{IC}_{50}\right)$ values (Table 2). The aqueous: methanol $(20: 80, \mathrm{v} / \mathrm{v})$ extract of $T$. schimperi demonstrated stronger percentage of $\alpha$-amylase enzyme inhibitory activity than the rest of the extracts. As positive control, acarbose showed the strongest $\alpha$-amylase inhibition activity, five times stronger than the inhibition potential of aqueous: methanol (20: 80, v/v) extract of $T$. schimperi . Whereas, hot extract of $T$. vulgaris showed the lowest $\alpha$-amylase inhibition activity $\left(\mathrm{IC}_{50}>2.5 \mathrm{mg} / \mathrm{ml}\right)$. There were significant differences $(p<0.05)$ in the $\mathrm{IC}_{50}$ values among the extracts. But $\alpha$-amylase enzyme inhibitory activities of these extracts were significantly lowers $(p<0.05)$ than the $\alpha$-amylase enzyme inhibitory activity of acarbose. The $\alpha$-amylase inhibition capacity of aqueous: methanol (20: 80, v/v) extract of T. schimperi of our previous study (Engeda et al., 2015) was weaker $\left(\mathrm{IC}_{50}=0.44 \mathrm{mg} / \mathrm{mL}\right)$ than that of the present study $\left(\mathrm{IC}_{50}=0.33 \mathrm{mg} / \mathrm{mL}\right)$. This variation may be because of the geographical location and growing conditions of T. schimperi, such as soil and climate (Yang et al., 2018).

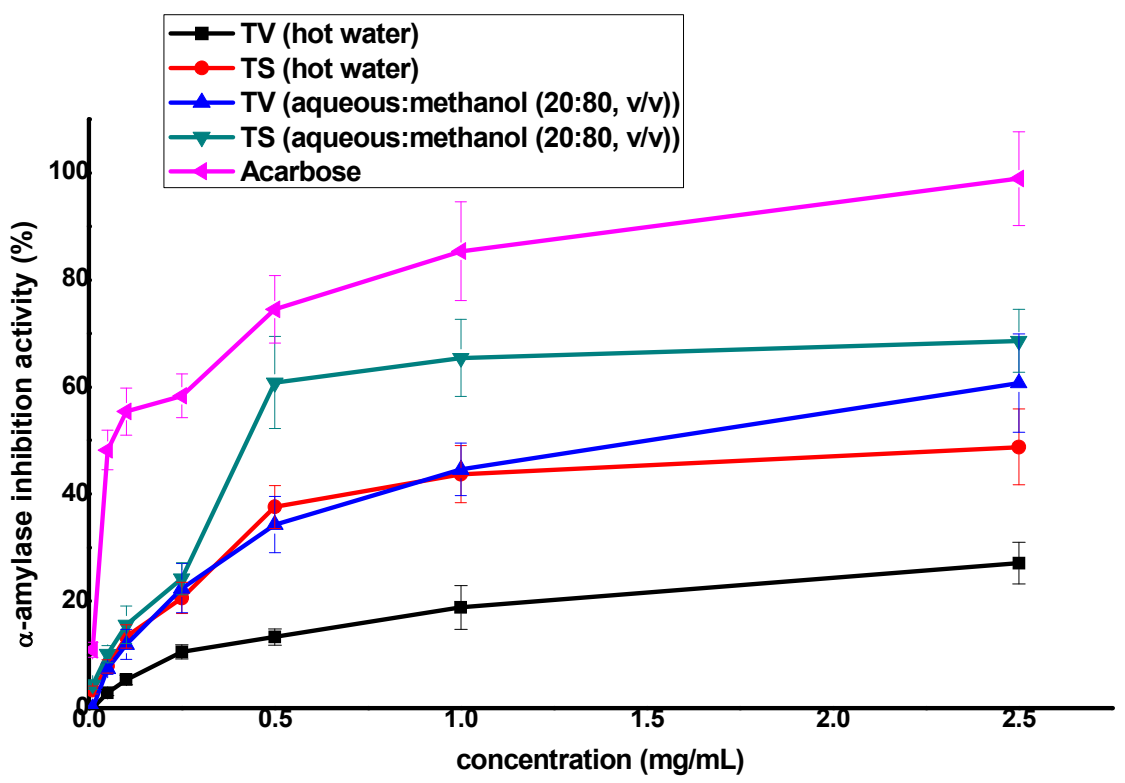

Figure 1. The porcine $\alpha$-amylase inhibitory activities of aqueous: methanol (20: 80, v/v) and boiling water extracts of T. schimperi and T. vulgaris. Results were expressed as mean $\pm \operatorname{SD}(n=3)$.

\subsection{In vitro $\alpha$-glycosidase inhibition activity}

The extracts were also tested through the $\alpha$-glucosidase inhibitory assay and the results were shown in Figure 2 . At the concentration of $2.5 \mathrm{mg} / \mathrm{mL}$, hot water extract of $T$. schimperi showed the highest a-glucosidase inhibition activity $(96.8 \pm 10.5 \%)$ followed by hot water extract of $T$. vulgaris $(86.7 \pm 8.3 \%)$, aqueous: methanol $(20: 80, \mathrm{v} / \mathrm{v})$ 
extract of $T$. schimperi $(84.4 \pm 8.5 \%)$, aqueous: methanol $(20: 80, \mathrm{v} / \mathrm{v})$ extract of $T$. vulgaris $(60.7 \pm 9.2 \%)$ and acarbose $(65.4 \pm 5.8 \%)$.

The $\mathrm{IC}_{50}$ values were shown in Table.2. Hot water extract of $T$. schimperi showed strongest $\alpha$-glucosidase inhibition activity ten times stronger than that of aqueous: methanol (20:80, v/v) extract of $T$. vulgaris and more than four times stronger than the $\alpha$-glucosidase inhibition activity of hot water extract of $T$. vulgaris and more than thirteen times stronger than that of $\alpha$-glucosidase inhibition activity and acarbose. There was no significant difference in $\mathrm{IC}_{50}$ values $(\mathrm{p}>0.05)$ between aqueous: methanol $(20: 80, \mathrm{v} / \mathrm{v})$ extract of $T$. schimperi and acarbose in their $\alpha$-glucosidase inhibitory effects. But these values were significantly different from that of hot water extracts and aqueous: methanol $(20: 80, \mathrm{v} / \mathrm{v})$ extract of $T$. vulgaris. Similar result was reported by Toshiyuki and Miyazawa (2012) on safflower (Carthamus tinctorius L). According to this study the different extracts exhibited stronger $\alpha$ glucosidase inhibition activity than acarbose. Similarly, according to the study conducted by Abid et al. (2014), ethyl acetate fraction of Thymelaea hirsute showed stronger $\alpha$-glucosidase inhibition potential than that of acarbose. The hot water extracts of T. schimperi and T. vulgaris as natural sources thus can be potentially used to suppress glycemic load by reducing $\alpha$-glucosidase activity.

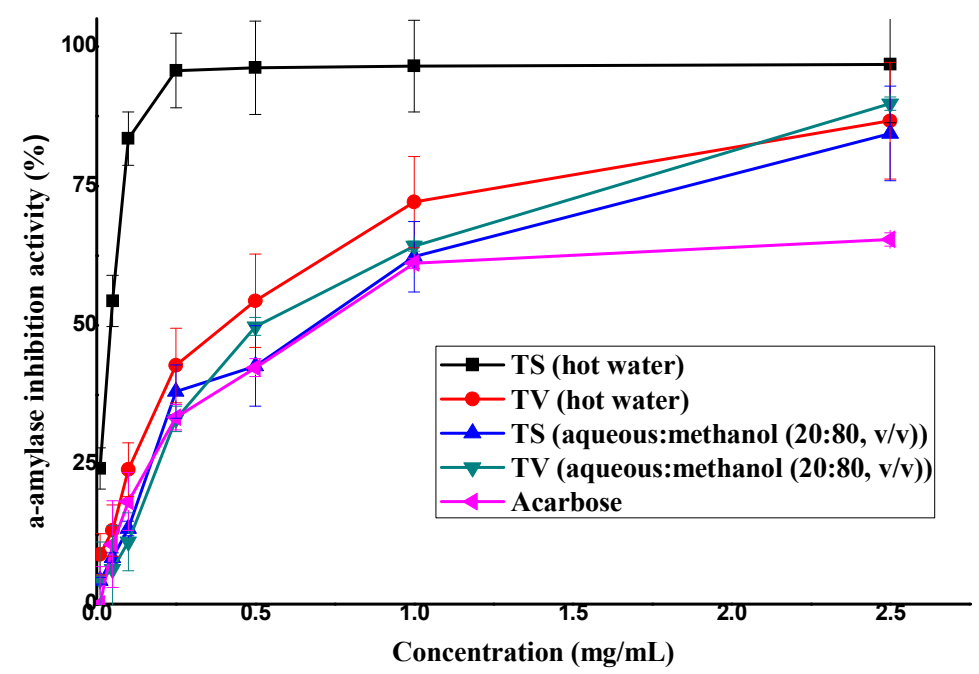

Figure 2. $\alpha$-glucosidase inhibitory activity of aqueous; methanol $(20: 80, \mathrm{v} / \mathrm{v})$ and boiling water extracts of $T$. schimperi and T. vulgaris. Results were expressed as mean $\pm \mathrm{SD}(n=3)$.

Table 2. $\mathrm{IC}_{50}(\mathrm{mg} / \mathrm{mL})$ of $\alpha$-amylase and $\alpha$-glucosidase inhibition activity of $T$. schimperi and $T$. vulgaris leaf extracts.

\begin{tabular}{lll}
\hline Extract & $\alpha-$ amylase & $\alpha$-glucosidase \\
\hline TS (aqueous: methanol:20:80, v/v) & $0.33 \pm 0.05^{\mathrm{b}}$ & $0.69 \pm 0.04^{\mathrm{d}}$ \\
TS (hot water) & $2.24 \pm 0.53^{\mathrm{d}}$ & $0.05 \pm 0.01^{\mathrm{a}}$ \\
TV (aqueous: methanol:20:80, v/v) & $1.56 \pm 0.09^{\mathrm{c}}$ & $0.51 \pm 0.02^{\mathrm{c}}$ \\
TV (hot water) & $>2.50$ & $0.24 \pm 0.09^{\mathrm{b}}$ \\
Acarbose & $0.07 \pm 0.01^{\mathrm{a}}$ & $0.71 \pm 0.12^{\mathrm{d}}$ \\
\hline
\end{tabular}

TS: Thymus schimperi; TV: Thymus vulgaris. Values are expressed as mean \pm SD $(\mathrm{n}=3)$ from triplicate experiments. Means with different letters in a column were significantly different at the level of $p<0.05$.

\subsection{Correlation Analysis}

The analyses of linear correlation between enzymes' inhibitory activities and TPC and TFC (Table 3 ) showed that the inhibitory effects of samples against the activity of $\alpha$-amylase could be due to the levels of phenolic compounds existing in the extracts with the correlation coefficients $+0.78,+0.67$, at $p<0.05$, respectively. These results suggest that higher phenolic content does confer higher $\alpha$-amylase inhibitory activity. Inhibitory activities of the extracts against $\alpha$-glucosidase were negatively proportional to both TPC and TFC, and the correlation coefficients were $\mathrm{R}^{2}=-0.22,-0.24$, at $p>0.05$, respectively. Several studies have found a direct correlation between the amount of phenolic compounds in plant extracts and their capacity to inhibit $\alpha$-enzymes (Patrick et al., 2005; Chen \& Kang, 2014). However, not always plant extracts with the high phenolic content have been demonstrated to exert the inhibitory activity on $\alpha$-amylase (Hairong and Baojun, 2014), which points out the importance of the 
nature of the different molecules and the interactions among them. Furthermore, different studies confirmed the negative correlation between phenolic contents and $\alpha$-glucosidase inhibition activity. According to the result reported by Jeonga et al. (2013), $\alpha$-glucosidase inhibition activity of Rehmannia glutinosa tuberous root extracts was negatively correlated with TPC. To the contrary the study conducted by Hairong and Baojun (2014) on onion, reported that TPC values of samples were positively correlated to $\alpha$-glucosidase and negatively correlated with $\alpha$ amylase inhibitory activities. Silva Pinto et al. (2009), have also shown a positive correlation between $\alpha$ glucosidase activity and TPC of Gingko bilibo L. leaves extracts.

Table 3. Correlations between enzyme inhibition activity and total phenolic and flavonoid contents.

\begin{tabular}{lll}
\hline Inhibition Activity & TPC $(\mathrm{mgGAE} / \mathrm{g} \mathrm{dw})^{*}$ & TFC $(\mathrm{mgQRE} / \mathrm{g} \mathrm{dw})^{* *}$ \\
\hline$\alpha$-amylase & +0.78 & -0.22 \\
$\alpha$-glucosidase & +0.67 & -0.24 \\
\hline
\end{tabular}

Where $*$ and $* *$ are total phenolic and total flavonoids expressed as gallic acid and quercetin equivalents, respectively; dw: dried weight of plant material.

\section{Conclusion}

The present investigation showed that the in vitro antidiabetic properties of $T$. schimperi and T. vulagaris were related with their $\alpha$-glucosidase and $\alpha$-amylase inhibitory effects. Hot water extract of $T$. schimperi had stronger $\alpha$-glucosidase inhibitor and aqueous: methanol $(20: 80, \mathrm{v} / \mathrm{v})$ extract showed stronger $\alpha$-amylase inhibitory potential in comparison with T. vulgaris. These results also indicated that there was positive linear correlation between TPC and $\alpha$-amylase inhibition activity but negatively correlated with $\alpha$-glucosidase inhibitory activity. However, phenolic compounds may not be the only class of active compounds to contribute to antidiabetic effects of these two herbs. The $\alpha$-glucosidase inhibition activity of hot water extract of $T$. schimperi was much stronger than that of the standard drug acarbose and thus this extract might help in the identification of new lead molecules for natural $\alpha$-glucosidase inhibitors. However isolation and characterization of the active compounds associated with $\alpha$ amylase and $\alpha$-glucosidase inhibition have to be carried out to confirm these observations. It can be therefore concluded from this study that the presence of the phytochemicals in these plants might be the reason for these inhibitions and that the plants may essentially contain herbal bioactive compounds which require further structural elucidation and characterization to identify the specific bioactive constituents. Also further in vivo and clinical investigations should be done for confirming the antidiabetic activity of these dietary herbs.

\section{Acknowledgements}

The financial support provided by the Addis Ababa University, and Hawassa College of Education is fully and gratefully acknowledged. We would also like to acknowledge Department of Environmental Sciences, Faculty of Agriculture, Dalhousie University, Canada for the use of laboratory facilities.

\section{Conflicts of interest}

The authors declare that they have no conflicts of interest.

\section{References}

Abdullah, D., \& Izabela, K. 2013. Phenolic contents, antioxidant capacities and inhibitory activities against key metabolic syndrome relevant enzymes of herbal teas from Eastern Anatolia, Industrial Crops and Products, 44:383-390

Abid, S., Lekchiri, A., Mekhfi, H., Ziyyat, A., Legssyer, A., Aziz, M. \& Bnouhami, M. 2014. Inhibition of $\alpha-$ glucosidase and glucose intestinal absorption by Thymelaea hirsuta fractions, Journal of Diabetes, 6(4): 351359.

Ahmed., O. M., Moneim., A. A., Yazid, I. A. \& Mahmoud, A M. 2010. Antihyperglicemic antihyperlipidemic and antioxidant effects and the probable mechanisms of action of Ruta graveolens infusion and rutin in nicotinamide-streptozotocin-induced diabetic rats, Diabetologia Croatica, 39(1): 15-35.

Al-Bayati., F. A. 2008. Synergistic antibacterial activity between Thymus vulgaris and Pimpinella anisum essential oils and methanol extracts, Journal of Ethnopharmacology, 166(3): 403-406.

Ayoola, G., Ipav, S., Solidiya, M., Adepoju-Bello, A., Coker, H. \& Odugbemi, T. 2008. Phytochemical screening and free radical scavenging activities of the fruits and leaves of Allanblackia floribunda oliv. (Guttiferae), International Journal of Health Research, 1: 81-93.

Castañeda-Ovando, A., Pacheco-Hernández, ML., Galán-Vidal, P-H., Elena, M., Rodríguez, JA. \& Andrés, C. 2009. Chemical studies of anthocyanins: A review. Food Chemistry, 113(4): 859-871.

Cazzola R., Camerotto, C. \& Cestaro, B. 2011. Antioxidant, antiglycant, and inhibitory activity against $\alpha$-amylase and $\alpha$-glucosidase of selected spices and culinary herbs, International Journal Food Science and Nutrition, 62: $175-84$.

Chan, H-H., Sun, H-D., Reddy, MVB. \& Wu, T-S. 2010. Potent $\alpha$-glucosidase inhibitors from the roots of Panax 
japonicus C. A. Meyer var. major, Phytochemistry, 71: 1360-1364.

Chen, L. \& Kang, Y. H. 2014. In vitro inhibitory potential against key enzymes for hyperglycemia and hypertension of red pepper (Capsicum annuum L.) including pericarp placenta and stalk, Journal of Food Biochemistry, 38: 300-306.

Cheplick, S., Kwon, Y., Bhowmik, P. \& Shetty, K. 2010. Phenolic-linked variation in strawberry cultivars for potential dietary management of hyperglycemia and related complications of hypertension, Bioresource Technology, 101: 404-413.

Engeda, D., Geremew, B., Gulelat, D. H. \& H. P. Vasantha Rupasinghe. 2015. Antioxidant and $\alpha$-amylase inhibition activities in vitro of various solvent extracts of Thymus schimperi Ronniger. Journal of medicinal plant research, 9(15): 515-524.

Esther E. N., Emmanuel, O. \& Ganiyu, O. 2013. Inhibitory effects of methanolic extracts of two eggplant species from South-western Nigeria on starch hydrolyzing enzymes linked to type-2 diabetes, African Journal of Pharmacy and Pharmacology, 7(23): 1575-1584.

Golmakani, M. T. \& Rezaei, K. 2008. Comparison of microwave-assisted hydrodistillation with the traditional hydrodistillation method in the extraction of essential oils from Thymus vulgaris L, Food chemistry, 109(4): 925-930.

Hairong, Wu. \& Baojun, Xu. 2014. Inhibitory effects of onion against $\alpha$-glucosidase activity and its correlation with phenolic antioxidants, International Journal of Food Properties, 17(3): 599-609.

Hasya, N. E., Didem, D. O., İlkay, E. O., Nilüfer, O. \& Mustafa, A. 2019. Evaluation of enzyme inhibitory and antioxidant activity of some Lamiaceae plants, Journal of Research in Pharmacy, 23(4): 749-758.

Ivan L. L., Alicia, M. A., Suad, N. \& Mohammad, M. 2012. $\alpha$-Glucosidase inhibitory activity of selected Philippine plants, Journal of Ethnopharmacology, 144(1): 217-219.

Jayaprakasam, B., Vareed, S. K., Olson, K. L. \& Nair, M. G. 2005. Insulin secretion by bioactive anthocyanins and anthocyanidins present in fruits, Journal of Agricultural and Food Chemistry, 53(1): 28-31.

Jeonga, H. J., Kimb, J. S., Hyunc, K. T., Yanga, J., Kangd, H. H., Chod, J. C., Yeomd, H. M. \& Myong, J. K. 2013. In vitro antioxidant and antidiabetic activities of Rehmannia glutinosa tuberous root extracts, Science Asia, 39:605-609.

John, R.N., Taylor, Peter, S., Belton, T. B. \& Kwaku, G. D. 2014. Increasing the utilisation of sorghum, millets and pseudocereals: Developments in the science of their phenolic phytochemicals, biofortification and protein functionality, Journal of Cereal Science, 59:257-275.

Jumepaeng, T., Prachakool, S., Luthria, D. L. \& Chanthai, S. 2013. Determination of antioxidant capacity and $\alpha-$ amylase inhibitory activity of the essential oils from citronella grass and lemongrass, International Food Research Journal, 20:481- 485 .

Kati, H., Riitta, T., Isabel, B., Jenna, P., Marjukka, K., Hannu, M. \& Kaisa, P. 2010. Impact of Dietary Polyphenols on Carbohydrate Metabolism, International Journal of Molecular Science, 11:1365-1402.

Kim, J. S., Hyun, T.K. \& Kim, M. J. 2011. The inhibitory effects of ethanol extracts from -amylase activities, $\alpha-$ glucosidase and asorghum, foxtail millet and proso millet. Food Chemistry. 124:1647-65.

Kwon, Y. I., Apostolidis, E. \& Shetty, K. 2008. In vitro studies of eggplant (Solanum melongena) phenolics as inhibitors of key enzymes relevant for type 2 diabetes and hypertension, Bioresoure Technology, 99:29812988.

McDougall, G. J., Shpiro, F., Dobson, P., Smith, P., Blake, A. \& Stewart, D. 2005. Different Polyphenolic Components of Soft Fruits Inhibit $\alpha$-Amylase and $\alpha$-Glucosidase, Journal of Agricultural and Food Chemistry, 53(7): 2760-2766.

Miaad, S. \& Saeed, S. 2017. The Antidiabetic and Antioxidant Effects of Carotenoids: A Review, Asian Journal of Pharmaceutical Research and Health Care, 9(4): 186-191, 2017.

Misbah, H., Abdul Aziz, A. \& Aminudin, N. 2013. Antidiabetic and antioxidant properties of Ficus deltoidea fruit extracts and fractions, Complementary and Alternative Medicine, 13:118-124.

Mustafa, A., Nilufer, O., Didem, D. O. \& Fatma, E. 2010. Hypoglycemic activity and antioxidant potential of some medicinal plants traditionally used in Turkey for diabetes, Journal of Ethnopharmacology, 128: 384389

Nigist A, Sebsebe D. 2009. Aromatic Plants of Ethiopia, Shama books, Addis Ababa, Ethiopia, pp: 137-138.

Oboh, G., Akinyemi, AJ. \& Ademiluyi, AO. 2012. Inhibition of $\alpha$-amylase and alucosidase activities by ethanolic extract of Telfairia occidentalis (fluted pumpkin) leaf, Asian Pacific Journal of Tropical Biomedicine, 2(9): 733-738.

Patrick, M., Young, K. \& Kalidas, S. 2005. Anti-amylase, Anti-glucosidase and antiangiotensin I- converting Enzyme Potential of Selected Foods, Journal of Food Biochemistry, 25(3): 278-294.

Probhakar, P. \& Doble, M. 2011. Mechanism of action of natural products used in the treatment of diabetes mellitus, Chinese Journal of Integrative Medicine, 17: 563-574.

Randhir, R., Kwon, Y. I. \& Shetty, K. 2008. Effect of thermal processing on phenolics, antioxidant activity and 
health-relevant functionality of select grain sprouts and seedlings, Innovative Food Science and Emerging Technologies, 9: 355-364.

Ranilla, L. G., Kwon, Y. \& Shetty, K. 2010. Phenolic compounds, antioxidant activity and in vitro inhibitory potential against key enzymes relevant for hyperglycemia and hypertension of commonly used medicinal plants, herbs and spices in Latin America, Bioresourse Technology, 101: 4676-89.

Rime, B. E., dorota, K., Louise, C. B. O., Summangala, E., Lars, P. C., Kai., G., Niels., O., Nils., F., Karsten., K. \& Kathrine, B. C. 2014. Screening for Bioactive Metabolites in Plant Extracts Modulating Glucose Uptake and Fat Accumulation; Evidence Based Complementary Alternative Medicine, 1-8.

Shakeera, B. M., Sujatha, K., Sridharan, G. \& Mannikandan, R. 2013. Antihyperglycemic and antihyperlipidemic potentials of Psidium guajava in alloxan- induced diabetic rats, Asian Journal of Pharmaceutical and Clinical Research, 6 (1): 88-89.

Shan B, Cai Y, Sun M, Corke H 2005. Antioxidant capacity of 26 spice extracts and characterization of their phenolic constituents, Journal of Agricultural and Food Chemistry, 53(20): 7749-7759.

Shobana, S., Sreerama, Y. N. \& Malleshi, N. G. 2009. Composition and enzyme inhibitory properties of finger millet (Eleusine coracana L.) seed coat phenolics: mode of inhibition of $\alpha$-glucosidase and pancreatic amylase, Food Chemistry, 115(4): 1268-1273.

Silva Pinto, M. D., Kwon, Y. I., Apostolidis, E., Lajolo, F. M., Genovese, M.I. \& Shetty, K. 2009. Potential of Gingko biloba L. leaves in the management of hyperglycemia and hypertension using in vitro models, Bioresource Technology, 100: 6599-6609.

Soon, H. T., Chung, Y. L., Hazrina, H., Aditya, A., Mohammadjavad, P., Won, F. W., Shiau-Chuen., C., Mohd, R. M. \& Khalijah, A. 2013. Antidiabetic and Antioxidant Properties of Alkaloids from Catharanthus roseus (L.), Molecules, 18(8): 9770-9784.

Toshiyuki,T. \& Miyazawa, M. 2012. Potent a-Glucosidase Inhibitors from Safflower (Carthamus tinctorius L.) Seed, Phytotherapy Research, 26: 722-726.

Wadkar, K., Magdum, C., Patil, S. \& Naikwade, N. 2008. "Anti-diabetic potential and Indian medicinal plants", Journal Herbal Medicinal Toxicology, 2(1): 45-50.

Wenli, H., Yanfang, L., Qiang, Z.., Xin, W. Aihua, P., Lijuan, C. \& Yuquan, W. 2009. Triterpene acids isolated from Lagerstroemia speciosa leaves as $\alpha$-glucosidase inhibitors, Phytotherapy Research, 23: 614-618.

Wongsa, P., Chaiwarit, J. \& Zamaludien, A. 2012. In vitro screening of phenolic compounds, potential inhibition against $\alpha$-amylase and $\alpha$-glucosidase of culinary herbs in Thailand, Food Chemistry, 131(3): 964-971.

Yang, L., chen, P., mingming, Z., Tongli, W., Shengzuo, F., Xulan, S. \& Xiagxang F. 2018. Geographic Variation in the Chemical Composition and Antioxidant Properties of Phenolic Compounds from Cyclocarya paliurus (Batal) Iljinskaja Leaves, Molecules, 23(10): 1-12.

Yang, Z., Wang, Y., Wang, Y. \& Zhang, Y. 2012. Bioassay-guided screening and isolation of $\alpha$-glucosidase and tyrosinase inhibitors from leaves of Morus alba, Food Chemistry, 131(2): 617-625. 